\title{
IMPACT OF WEATHER CONDITIONS ON THE ENERGETIC QUALITY OF ACICULATED DRY BRANCHES OF Araucaria angustifolia (Bertol.) Kuntze PRODUCED THROUGHOUT A YEAR
}

\author{
Taíse Mariano Rodrigues ${ }^{1}$, Tássio Dresch Rech ${ }^{2}$, Tiago Celso Baldissera ${ }^{2}$, Cassiano Eduardo Pinto ${ }^{2}$, Fabio Cervo \\ Garagory $^{3}$, Martha Andreia Brand ${ }^{1 *}$ \\ ${ }^{1}$ Universidade do Estado de Santa Catarina, Curso de Mestrado em Engenharia Florestal, Lages, Santa Catarina, Brazil \\ taise.udesc@hotmail.com, ${ }^{1 *}$ martha.brand@udesc.br \\ ${ }^{2}$ Empresa de Pesquisa Agropecuária e Extensão Rural de Santa Catarina - EPAGRI - Estação Experimental Lages, Lages, Santa Catarina, \\ Brazil -tassior@epagri.sc.gov.br, tiagobaldissera@epagri.sc.gov.br, cassiano@epagri.sc.gov.br, \\ ${ }^{3}$ Empresa Brasileira de Pesquisa Agropecuária - Embrapa Pecuária Sul, Bagé, Rio Grande do Sul, Brazil - fabio.garagorry@embrapa.br
}

Received for publication: 17/04/2020 - Accepted for publications: 23/10/2020

\begin{abstract}
Resumo
Impacto das condições climáticas na qualidade energética da grimpa produzida ao longo do ano pela Araucaria angustifolia (Bertol.) Kuntze. Os galhos secos aciculados da Araucaria angustifolia (grimpas), que caem ao longo do ano no solo pela derrama natural da espécie, podem ser fonte renovável e sustentável de energia e renda para os produtores rurais inseridos na Floresta Ombrólifa Mista. O objetivo deste trabalho foi caracterizar energeticamente a biomassa da grimpa de A. angustifolia produzida ao longo do ano por árvores de crescimento livre em campos naturais de altitude na região serrana de Santa Catarina e determinar a influência das condições climáticas na qualidade energética da grimpa. Foram demarcadas 37 árvores, com a escolha de um quadrante em função do raio da copa, no qual as grimpas foram coletadas mensalmente, entre junho de 2018 a maio de 2019. Posteriormente, foram determinadas as propriedades físicas, químicas e energéticas da biomasssa. A correlação simples entre as variáveis climáticas e as propriedades físicas, química e energéticas foi determinada. A principal vantagem das grimpas como recurso energético foi seu baixo teor de umidade (18\%) e as desvantagens foram o elevado teor de cinzas $(5,8 \%)$ e a baixa densidade básica $\left(220 \mathrm{~kg} . \mathrm{m}^{-}\right.$ ${ }^{3}$ ). Com exceção do teor de umidade, todas as demais propriedades físicas, químicas e energéticas da grimpa variaram ao longo do ano e sofreram influência das variáveis climáticas. As correlações entre as variáveis climáticas e as propriedades analisadas indicaram que a qualidade energética das grimpas foi melhor nos meses de verão, com os maiores valores de temperaturas médias mensais e radiação solar.

Palavras-chaves: biomassa seca, árvores de crescimento livre, combustível sólido, energia renovável.
\end{abstract}

\begin{abstract}
The aciculated dry branches of Araucaria angustifolia, which fall throughout the year by the natural pruning of the species, can be a renewable and sustainable alternative for energy generation and income for rural producers inserted in the Mixed Ombrophilous Forest. This research aimed to energetically characterize these dry branches produced by free-growing trees throughout the year in the Santa Catarina's Plateau Region. Also, it aimed to determine the influence of weather conditions on the energetic quality of the aciculated dry branches. To that end, we demarcated 37 trees by choosing a quadrant according to the radius of the crowns in which the dry branches were collected. Collections happened monthly between June 2018 and May 2019. Subsequently, the biomass's physical, chemical, and energetic properties were determined. A simple correlation between climatic variables and properties was obtained. The main advantage of aciculated dry branches as an energy resource was their low moisture content $(18 \%)$ and the disadvantages were the high ash content and the low basic density $\left(220 \mathrm{~kg} \cdot \mathrm{m}^{-3}\right)$. Except for the moisture content, all the properties of the aciculated dry branches varied throughout the year, and they were influenced by the weather variables. The correlations between the climatic variables and the properties analyzed indicated that the energetic quality of the dry branches was better in the months with the highest values of average temperatures and solar radiation.

Keywords: dry biomass, free-growing trees, solid fuel, renewable energy.
\end{abstract}

\section{INTRODUCTION}

The Mixed Ombrophilous Forest (FOM) or Araucaria Forest is a phytophysiognomy of the Southern Plateau inserted in the Atlantic Forest's biome. It is characterized by the occurrence of Araucaria angustifolia (Bertol.) Kuntze (IBGE, 2012). It is one of the main forest formations in the southern region of Brazil. Its larger area of geographic distribution is associated with places of high altitude and low annual average temperatures, occurring in association with natural fields of altitude, predominantly, in the southern plateau (HIGUCHI et al., 2012). In the Santa Catarina's plateau, natural fields are commonly used for cattle raising and they have as one of their landscape components free-growth $A$. angustifolia trees. In addition, the extraction of mate is also an economic activity that contributes to the conservation of the FOM.

This species has undergone heavy exploitation over the years due to the quality and durability of its wood (DANNER et al., 2012), and it is currently protected by the Atlantic Forest's Law No. 11,428, of 22 December 
2006 (BRASIL, 2006). Nowadays, this species presents a greater non-timber forest potential, such as the use of its seed, which is a nutritious and energetic food, and aciculated dry branches. The dry branches fall to the ground throughout the year because of the senescence process, which causes natural pruning (RIOS et al., 2015; ZANETTE et al., 2017). They can be defined as secondary and flexible branches with anatropic growth (ZANETTE et al., 2017), and they represent an important portion of the biomass produced by A. angustifolia trees. Therefore, they are an energetic resource that can be used in southern Brazil (BRAND et al., 2018).

Regarding energy generation, it should be noted that the regions where the araucaria naturally occurs have a mild climate with severe winters. Due to this weather condition, alternative use for the dry branches would be its energetic application as an alternative fuel for residential or commercial heating systems. Furthermore, the energetic application could be mainly in the form of a solid fuel, which minimizes the treatment steps before usage.

The production of dry branches, which contributes significantly to the formation of forest litter, can be affected by several biotic and abiotic factors such as vegetation type, altitude, latitude, precipitation, temperature, light regimes, landform, water availability, soil characteristics, and others. Depending on the characteristics of the ecosystem, one or more of these factors may stand out over the others (CALVI et al., 2009).

Watzlawick et al. (2012) quantified average biomass stored in the Montana Mixed Rainforest of 250.90 $\mathrm{Mg} / \mathrm{ha}$, and the accumulated litter of $A$. angustifolia represented $8.22 \%$ of the dead branches (near two tons). Also, Beutling et al. (2005) quantified the fuel material on the surface of reforestation of A. angustifolia and concluded that the "miscellany" (38.6\%) and the "aciculated dry branches" $(30.46 \%)$ were the classes that participated the most in the constitution of the total biomass load.

Currently, farmers collect the dry branches from the fields and burn them. They report losses as cattle reject pasture areas covered by araucaria dry branches. In addition, they report physical injuries to the animals' airways which causes economic losses. Thus, studies related to the use of all the components of A. angustifolia trees, such as the production of pine nuts and the use of the dead dry branches, would be an effective way to reduce the pressure on the remaining araucaria and make its conservation and cultivation economically profitable.

Hence, it is important to carry out studies to get to know the changes in the energetic properties of the aciculated dry branches throughout the year due to weather variations. These studies are essential mainly to establish the relationship between the weather variables and the energetic quality of the branches. Therefore, the objectives of this study were (a) to energetically characterize the dry branches of free-growing A. angustifolia trees produced throughout the year in the natural fields of high altitude in the mountainous region of Santa Catarina, and (b) to determine the influence of weather conditions in their energetic quality.

\section{MATERIALS AND METHODS}

We collected samples of A. angustifolia dry branches from 37 free-growing trees inside the EPAGRI's experimental farm $\left(27^{\circ} 45^{\prime} 19.5^{\prime \prime} \mathrm{S}\right.$ and $50^{\circ} 25^{\prime} 19,9$ ” W) in the altitude fields of São José do Cerrito, Santa Catarina, Brazil. We demarcated the sampling units (37 trees) and carried out the cleaning of the canopy projection between April and May 2018. After that, we carried out monthly collections from June 2018 to May 2019.

In each tree, we marked four canopy rays in the cardinal directions north, south, east, and west. Then we used these directions to delimit the perimeter of each of the four quadrants demarcated in the trees. In each tree, we randomly selected a quadrant demarcated by stakes for the monthly collections. After collecting the dry branches from the field, we packed them in airtight plastic bags for later determination of the recently collected moisture content. Moreover, we performed the energetic analysis monthly on samples composed of the 37 sample units under study.

For the physical, chemical, and energetic characterization, we crushed the biomass in a hammer mill with a $5 \mathrm{~mm}$ mesh opening. After grinding, we used the sawdust that went through a 40 mesh sieve and was retained in a 60 mesh sieve for analyzes. We stored the sawdust in an air-conditioned chamber with $65 \% \pm 2$ of relative humidity and a temperature of $22^{\circ} \mathrm{C} \pm 2$ until it reached a balanced humidity of $12 \%$.

The evaluated physical properties were: the moisture content (wet basis), according to the NBR 14929 standard (ABNT, 2017a), and the basic density, according to the NBR 11941 standard (ABNT, 2003). We evaluated the chemical composition by determining the content of water-soluble extracts, solubility in $1 \%$ sodium hydroxide concentration, and content of total extractives and lignin content, according to NBR 14577 (ABNT, 2017b), NBR 7990 (ABNT, 2010b), NBR 14660 (ABNT, 2004), and NBR 7989 (ABNT, 2010a), respectively. Also, we obtained the holocellulose (TH) content by using Equation 1.

$$
\mathrm{HC}=100-\mathrm{TE}-\mathrm{AC}-\mathrm{L} \quad \text { Equation } 1
$$

In which: $\mathrm{HC}=$ Holocellulose content $(\%) ; \mathrm{TE}=$ Total extractives $(\%) ; \mathrm{AC}=$ ash content $(\%) ; \mathrm{L}=$ Lignin content $(\%)$. 
Furthermore, we evaluated the following energetic properties: volatile content, ash content, and fixed carbon content (proximate analysis), according to ASTM D1762 (ASTM, 2013), and the gross calorific value, according to DIN 51900 (DIN, 2000). We also obtained the energetic density (DE) by using Equation 2.

$$
\mathrm{ED}=\mathrm{GDV} \times \mathrm{BD} \quad \text { Equation } 2
$$

In which: $\mathrm{ED}=$ Energetic density $\left(\mathrm{Mcal} . \mathrm{m}^{-3}\right) \mathrm{GCV}=$ gross calorific value $\left(\mathrm{Mcal}^{\mathrm{k}} \mathrm{kg}^{-1}\right) ; \mathrm{BD}=$ basic density $\left(\mathrm{kg} \cdot \mathrm{m}^{-}\right.$ $\left.{ }^{3}\right)$.

For all properties, we performed the analyzes in triplicate for each sample, obtaining the means and coefficient of variation.

During the study period, we obtained the average climatic variables of air temperature (MTa), relative humidity (RUa), wind speed $\left(\mathrm{km} \cdot \mathrm{h}^{-1}\right)$, average radiation $(\mathrm{MRa})$, and the sum of the season's rainfall (SR) at the closest EPAGRI's weather station to the study area.

We used a completely randomized experimental design with 12 repetitions and Scott Knott's test at a 95\% confidence level to compare the means. Furthermore, we obtained the Pearson's Correlation Coefficient between the physical, chemical, and energetic properties of the biomass and the weather variables by using the SISVAR statistical package. And then we used the Minitab 19 software to perform the Pearson's Correlation Coefficient significance test.

\section{RESULTS}

Table 1 shows the physical, chemical, and energetic properties of the aciculated dry branches collected monthly from June 2018 to May 2019.

Table 1 - Physical and energetic characterization of the aciculated dry branches collected during one year from free-growing trees in altitude fields in Santa Catarina

Tabela 1 - Caracterização física e energética de grimpas coletadas durante um ano de araucárias em campos de altitude em Santa Catarina

\begin{tabular}{|c|c|c|c|c|c|c|c|}
\hline Collection & $\begin{array}{c}\text { MC in } \\
\text { natura } \\
(\%)\end{array}$ & $\begin{array}{c}\text { BD } \\
\left(\mathbf{k g} \cdot \mathrm{m}^{-3}\right)\end{array}$ & $\begin{array}{c}\text { GCV } \\
\left({\mathrm{kcal} . \mathrm{kg}^{-1}}^{-1}\right)\end{array}$ & $\begin{array}{c}\text { ED } \\
\left(\text { Mcal. } \mathbf{m}^{-3}\right)\end{array}$ & $\begin{array}{l}\mathrm{VC} \\
(\%)\end{array}$ & $\begin{array}{l}\mathrm{AC} \\
(\%)\end{array}$ & $\begin{array}{c}\text { FCC } \\
(\%)\end{array}$ \\
\hline January & $16^{\mathrm{a}}$ & $231^{\mathrm{a}}$ & $4691^{b}$ & $1085^{\mathrm{a}}$ & $73.0^{\mathrm{b}}$ & $6.2^{\mathrm{a}}$ & $20.8^{\mathrm{b}}$ \\
\hline February & $16^{\mathrm{a}}$ & $223^{b}$ & $4657^{\mathrm{b}}$ & $1037^{b}$ & $74.1^{\mathrm{a}}$ & $5.3^{\mathrm{f}}$ & $20.6^{\mathrm{b}}$ \\
\hline March & $17^{\mathrm{a}}$ & $224^{\mathrm{b}}$ & $4861^{\mathrm{a}}$ & $1090^{\mathrm{a}}$ & $74.1^{\mathrm{a}}$ & $5.5^{\mathrm{e}}$ & $20.4^{\mathrm{b}}$ \\
\hline April & $16^{\mathrm{a}}$ & $230^{\mathrm{a}}$ & $4807^{\mathrm{a}}$ & $1104^{\mathrm{a}}$ & $73.5^{\mathrm{a}}$ & $5.9^{d}$ & $20.7^{\mathrm{b}}$ \\
\hline May & $17^{\mathrm{a}}$ & $222^{c}$ & $4898^{\mathrm{a}}$ & $1085^{\mathrm{a}}$ & $73.6^{\mathrm{a}}$ & $6.0^{c}$ & $20.5^{\mathrm{b}}$ \\
\hline June & $22^{\mathrm{a}}$ & $211^{\mathrm{e}}$ & $4912^{\mathrm{a}}$ & $1037^{b}$ & $72.9^{\mathrm{b}}$ & $6.2^{\mathrm{a}}$ & $20.8^{\mathrm{b}}$ \\
\hline July & $23^{\mathrm{a}}$ & $205^{\mathrm{f}}$ & $4847^{\mathrm{a}}$ & $993^{c}$ & $73.5^{\mathrm{a}}$ & $6.1^{\mathrm{b}}$ & $20.4^{\mathrm{b}}$ \\
\hline August & $20^{\mathrm{a}}$ & $216^{\mathrm{d}}$ & $4830^{\mathrm{a}}$ & $1044^{b}$ & $72.9^{\mathrm{b}}$ & $6.3^{\mathrm{a}}$ & $20.8^{\mathrm{b}}$ \\
\hline September & $18^{\mathrm{a}}$ & $219^{c}$ & $4794^{\mathrm{a}}$ & $1048^{b}$ & $72.9^{\mathrm{b}}$ & $6.1^{\mathrm{b}}$ & $21.0^{\mathrm{b}}$ \\
\hline October & $22^{\mathrm{a}}$ & $205^{\mathrm{f}}$ & $4607^{c}$ & $943^{\mathrm{d}}$ & $72.1^{\mathrm{b}}$ & $5.8^{\mathrm{d}}$ & $22.1^{\mathrm{a}}$ \\
\hline November & $22^{\mathrm{a}}$ & $226^{\mathrm{b}}$ & $4599^{c}$ & $1039^{b}$ & $72.4^{\mathrm{b}}$ & $5.5^{\mathrm{e}}$ & $22.1^{\mathrm{a}}$ \\
\hline December & $11^{\mathrm{a}}$ & $232^{\mathrm{a}}$ & $4714^{\mathrm{b}}$ & $1094^{\mathrm{a}}$ & $74.6^{\mathrm{a}}$ & $5.2^{\mathrm{f}}$ & $20.2^{\mathrm{b}}$ \\
\hline Mean & 18 & 220 & 4768 & 1050 & 73.3 & 5.8 & 20.9 \\
\hline $\mathrm{CV}(\%)$ & 33.41 & 1.14 & 0.98 & 1.46 & 0.75 & 1.08 & 2.72 \\
\hline
\end{tabular}

Note: MC: Moisture content (wet basis); BD: Bulk density; VC: Volatiles content; AC: Ash content; FCC: Fixed carbon content; GCV: Gross calorific value; ED: Energetic density; CV: coefficient of variation. Average values followed by the same letter in the columns do not differ by the Scott-Knott test at a $5 \%$ probability level. 
Table 2 presents the structural chemical composition of the dry branches.

Table 2 - Structural chemical composition of the aciculated dry branches collected throughout one year from free-growing trees in altitude fields in Santa Catarina

Tabela 2 - Composição química estrutural da grimpa coletada ao longo do ano, em árvores de crescimento livre em campos de altitude na região Serrana de Santa Catarina

\begin{tabular}{ccccccccc}
\hline Coleta & ECW $(\%)$ & EHW $(\%)$ & $\mathbf{N a O H}_{1 \%}(\%)$ & EE $(\%)$ & EET $(\%)$ & TE $(\%)$ & L $(\%)$ & HC $(\%)$ \\
\hline January & $12.13^{\mathrm{c}}$ & $16.84^{\mathrm{c}}$ & $49.69^{\mathrm{a}}$ & $2.96^{\mathrm{b}}$ & $18.99^{\mathrm{a}}$ & $38.92^{\mathrm{a}}$ & $40.31^{\mathrm{d}}$ & $15.04^{\mathrm{e}}$ \\
February & $15.52^{\mathrm{a}}$ & $18.02^{\mathrm{b}}$ & $49.28^{\mathrm{a}}$ & $2.37^{\mathrm{e}}$ & $17.19^{\mathrm{b}}$ & $37.57^{\mathrm{b}}$ & $39.51^{\mathrm{f}}$ & $17.22^{\mathrm{d}}$ \\
March & $9.56^{\mathrm{g}}$ & $14.011^{\mathrm{f}}$ & $46.39^{\mathrm{b}}$ & $2.89^{\mathrm{c}}$ & $12.20^{\mathrm{g}}$ & $29.18^{\mathrm{e}}$ & $40.78^{\mathrm{c}}$ & $24.56^{\mathrm{a}}$ \\
April & $9.99^{\mathrm{f}}$ & $14.96^{\mathrm{d}}$ & $50.06^{\mathrm{a}}$ & $3.28^{\mathrm{a}}$ & $14.47^{\mathrm{e}}$ & $32.7^{\mathrm{c}}$ & $43.63^{\mathrm{a}}$ & $17.81^{\mathrm{c}}$ \\
May & $10.18^{\mathrm{f}}$ & $14.83^{\mathrm{d}}$ & $49.59^{\mathrm{a}}$ & $2.73^{\mathrm{d}}$ & $15.41^{\mathrm{d}}$ & $32.97^{\mathrm{c}}$ & $43.08^{\mathrm{a}}$ & $17.98^{\mathrm{c}}$ \\
June & $10.10^{\mathrm{f}}$ & $14.59^{\mathrm{e}}$ & $46.81^{\mathrm{b}}$ & $1.96^{\mathrm{g}}$ & $12.44^{\mathrm{g}}$ & $29.00^{\mathrm{e}}$ & $41.86^{\mathrm{b}}$ & $22.93^{\mathrm{b}}$ \\
July & $9.28^{\mathrm{h}}$ & $13.64^{\mathrm{h}}$ & $45.48^{\mathrm{b}}$ & $2.04^{\mathrm{f}}$ & $14.23^{\mathrm{e}}$ & $29.91^{\mathrm{d}}$ & $40.58^{\mathrm{d}}$ & $23.39^{\mathrm{b}}$ \\
August & $10.89^{\mathrm{d}}$ & $14.15^{\mathrm{f}}$ & $46.77^{\mathrm{b}}$ & $1.31^{\mathrm{i}}$ & $12.57^{\mathrm{g}}$ & $28.04^{\mathrm{f}}$ & $40.18^{\mathrm{d}}$ & $25.47^{\mathrm{a}}$ \\
September & $8.84^{\mathrm{i}}$ & $11.74^{\mathrm{j}}$ & $46.98^{\mathrm{b}}$ & $1.93^{\mathrm{g}}$ & $14.43^{\mathrm{e}}$ & $28.10^{\mathrm{f}}$ & $41.30^{\mathrm{c}}$ & $24.45^{\mathrm{a}}$ \\
October & $9.29^{\mathrm{h}}$ & $12.41^{\mathrm{i}}$ & $49.34^{\mathrm{a}}$ & $1.44^{\mathrm{h}}$ & $13.64^{\mathrm{f}}$ & $27.49^{\mathrm{g}}$ & $42.43^{\mathrm{b}}$ & $24.29^{\mathrm{a}}$ \\
November & $10.42^{\mathrm{e}}$ & $13.80^{\mathrm{g}}$ & $49.18^{\mathrm{a}}$ & $2.35^{\mathrm{e}}$ & $12.59^{\mathrm{g}}$ & $28.75^{\mathrm{e}}$ & $40.87^{\mathrm{c}}$ & $24.87^{\mathrm{a}}$ \\
December & $13.28^{\mathrm{b}}$ & $19.39^{\mathrm{a}}$ & $49.18^{\mathrm{a}}$ & $2.79^{\mathrm{d}}$ & $16.60^{\mathrm{c}}$ & $38.78^{\mathrm{a}}$ & $39.48^{\mathrm{f}}$ & $16.51^{\mathrm{d}}$ \\
\hline Mean & 10.80 & 14.88 & 48.23 & 2.34 & 14.56 & 31.78 & 41.18 & 21.21 \\
\hline CV $(\%)$ & 1.57 & 0.61 & 1.17 & 1.64 & 1.87 & 0.91 & 0.94 & 2.66 \\
\hline
\end{tabular}

Note: ECW: Extractives in cold water; EHW: Extractives in hot water; NaOH 1\%: Extractives in sodium hydroxide at 1\%; EE: Extractives in ethanol; EET: Extractives in ethanol-toluene; TE: Total extractives; L: Lignin content; HC: Holocellulose content. CV: coefficient of variation. Average values followed by the same letter in the columns do not differ by the Scott-Knott test at a 5\% probability level.

Moreover, Table 3 shows the correlations between the weather variables and the physical, chemical, and energetic properties.

Table 3 - Pearson's correlation between the weather variables and the chemical and energetic properties of the aciculated dry branches

Tabela 3 - Correlação de Pearson entre as variáveis climáticas e as propriedades químicas e energéticas da grimpa

\begin{tabular}{lccccccccccccc}
\hline & ED & GCV & BD & ECW & EHW & EE & EET & TE & L & AC & VC & FCC & NaOH \\
\hline MTa & $0.43^{\text {ns }}$ & $-0.58^{*}$ & $0.76^{*}$ & $0.55^{\text {ns }}$ & $0.60^{*}$ & $0.71^{*}$ & $0.66^{*}$ & $0.73^{*}$ & $-0.26^{\text {ns }}$ & $-0.64^{*}$ & $0.37^{\text {ns }}$ & $0.03^{\text {ns }}$ & $0.66^{*}$ \\
RUa & $-0.14^{\text {ns }}$ & $0.63^{*}$ & $-0.48^{\text {ns }}$ & $-0.52^{\text {ns }}$ & $-0.55^{\text {ns }}$ & $-0.17^{\text {ns }}$ & $-0.30^{\text {ns }}$ & $-0.45^{\text {ns }}$ & $0.71^{*}$ & $0.65^{*}$ & $-0.30^{\text {ns }}$ & $-0.03^{\text {ns }}$ & $-0.20^{\text {ns }}$ \\
MRa & $0.23^{\text {ns }}$ & $-0.73^{*}$ & $0.63^{*}$ & $0.59^{*}$ & $0.61^{*}$ & $0.33^{\text {ns }}$ & $0.50^{\text {ns }}$ & $0.60^{*}$ & $-0.62^{*}$ & $-0.64^{*}$ & $0.24^{\text {ns }}$ & $0.10^{\text {ns }}$ & $0.44^{\text {ns }}$ \\
\hline
\end{tabular}

Note: MTa: Monthly average temperature $\left({ }^{\circ} \mathrm{C}\right)$; RUa: Montly average relative humidity (\%); MRa: Monthly average radiation $\left(\mathrm{W} . \mathrm{m}^{-2}\right) ; \mathrm{ED}$ : Energetic density $\left(\mathrm{Mcal} . \mathrm{m}^{-3}\right)$; GCV: Gross calorific value $\left(\mathrm{kcal}_{\mathrm{kg}} \mathrm{kg}^{-1}\right)$; BD: Basic density $\left(\mathrm{kg} . \mathrm{m}^{-3}\right)$; ECW: Extractives in cold water $(\%)$; EHW: Extractives in hot water (\%); EE: Extractives in ethanol (\%); EET: Extractives in ethanol-toluene (\%); TE: Total extractives content (\%); L: Lignin content $(\%)$; AC: Ash content $(\%)$; VC: Volatile content $(\%)$; FCC: Fixed carbon content $(\%)$; NaOH $1 \%$ : Extractives in sodium hydroxide at $1 \%(\%)$. ns = non-significant correlation at a probability level of $5 \%$. $*$ significant correlation at a probability level of $5 \%$.

The weather variables that presented the strongest correlations with the dry branches' properties $(\mathrm{r} \geq 0.5)$ between at least one property were the monthly average air temperature (MTa), the relative humidity (RUa), and the average radiation (MRa). Figure 1 shows the annual variation of the weather variables used in this study which had some level of correlation with the physical, chemical, and energetic properties of the dry branches. 


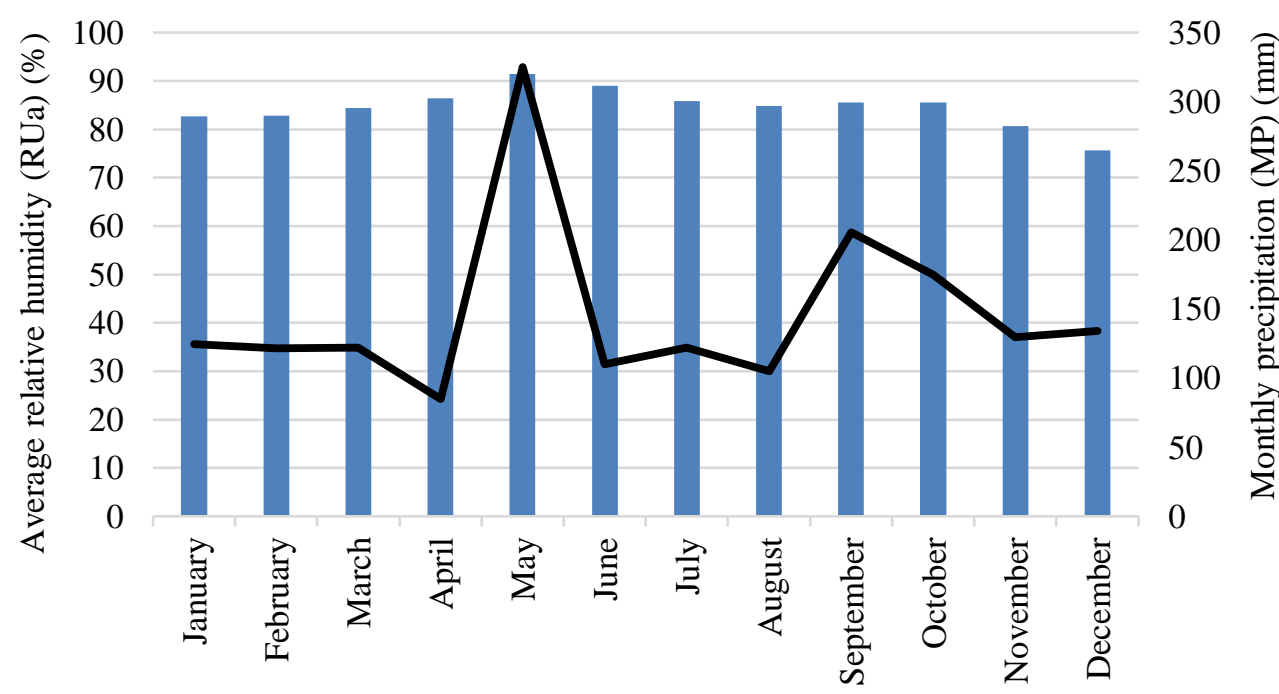

Collection periods

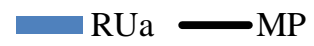

(a)

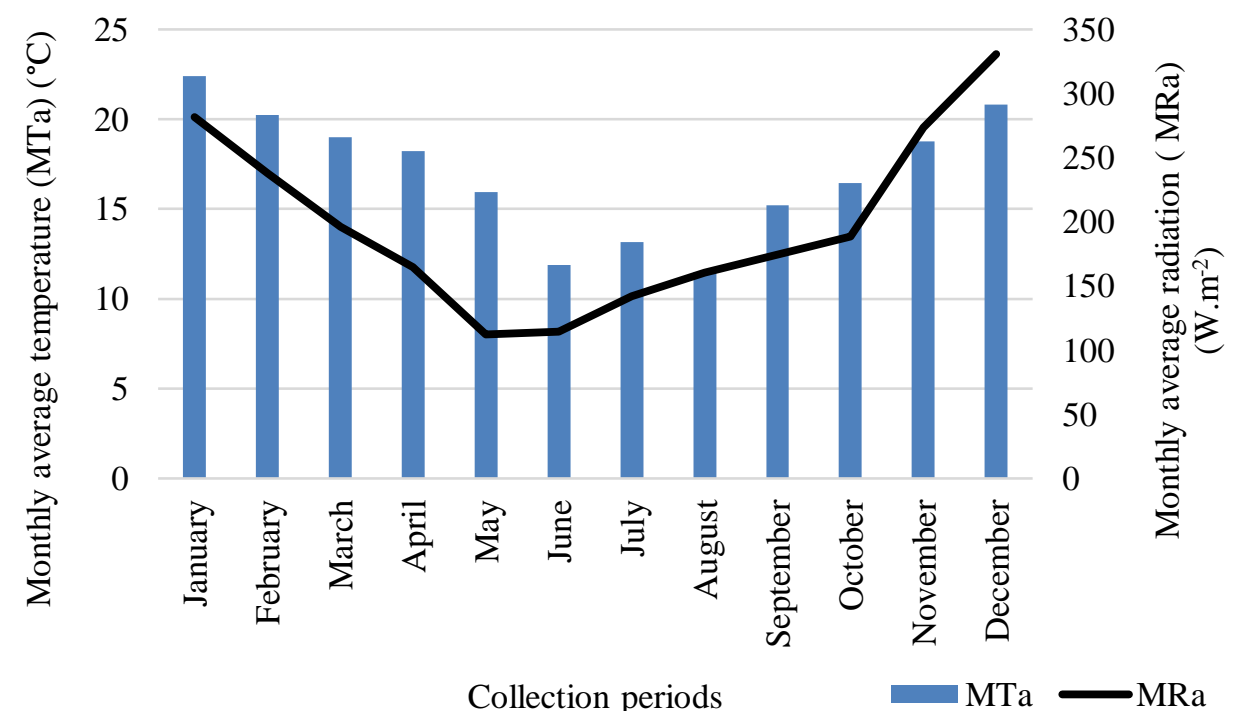

(b)

Figure 1 - Monthly average data of relative humidity x monthly accumulated precipitation (a), and air temperature $\mathrm{x}$ radiation (b) in the analyzed period.

Note: RUa: Monthly average relative humidity (\%); MP: Monthly accumulated precipitation (mm); MTa: Monthly average temperature $\left({ }^{\circ} \mathrm{C}\right)$; MRa: Monthly average monthly radiation $\left(\mathrm{W} \cdot \mathrm{m}^{-2}\right)$.

Figura 1 - Dados médios mensais da umidade relativa do ar x precipitação acumulada mensal (a), relação da temperatura do ar x radiação solar (b) no período de análise.

Nota: RUa: Umidade relativa média mensal (\%); MP: Precipitação acumulada mensal (mm); MTa: Temperatura média mensal $\left({ }^{\circ} \mathrm{C}\right)$; MRa: Radiação média mensal (W.m-2)

Table 4 presents the comparison between the values obtained in this study for the structural chemical composition of the aciculated dry branches and other recently published studies which used the same biomass. 
Table 4 - Comparison between the structural chemical composition of the aciculated dry branches from this study and the composition found by authors who studied this biomass from the same study region

Tabela 4 - Comparação da composição química estrutural da grimpa com autores que trabalharam com material da mesma região de estudo

\begin{tabular}{l|cc|cc|cc}
\hline \multirow{2}{*}{$\begin{array}{c}\text { Structural chemical } \\
\text { composition }\end{array}$} & \multicolumn{2}{c|}{ Our results } & \multicolumn{2}{c|}{ Rios et al. (2015) } & \multicolumn{2}{c}{ Brand et al. (2018) } \\
\cline { 2 - 7 } & $(\%)$ & CV $(\%)$ & $(\%)$ & CV $(\%)$ & $(\%)$ & CV $(\%)$ \\
\hline Ehw (\%) & 14.74 & 0.60 & 11.01 & 13.08 & 7.75 & 9.99 \\
EE (\%) & 2.28 & 1.68 & 1.37 & 27.74 & 0.56 & 16.47 \\
EET (\%) & 14.42 & 1.87 & 12.57 & 13.13 & 11.64 & 3.85 \\
TE (\%) & 31.46 & 0.92 & 24.95 & 9.3 & 19.96 & 2.86 \\
L (\%) & 41.22 & 0.93 & 47.41 & 4.2 & 42.16 & 3.56 \\
HC (\%) & 21.49 & 2.50 & 22.51 & 14.75 & 29.98 & 3.37 \\
\hline
\end{tabular}

Note: EHW: Extractives in hot water; EE: Extractives in ethanol (\%); EET: Extractives in ethanol-toluene (\%); TE: Total extractives (\%); L: Lignin content (\%); HC: Holocellulose content (\%); CV: Coefficient of variation.

\section{DISCUSSION}

The wet-basis moisture content (MC) of the dry branches shortly after the collection in the field was low in all analyzed months with no significant variation between the average values (Table 1). According to Brand (2010), the biomass' MC for direct burning must be less than 30\%. In this way, the dry branches could be used directly for power generation without the need for prior drying or treatment.

The reduced moisture content right after collection represents an advantage in terms of energy, operational gains, and lower transport costs when compared to other lignocellulosic biomass fuels such as wood. The Pinus and Eucalyptus wood from the same study region presented moisture contents between 50 and $65 \%$ when freshly harvested at different times of the year (BRAND et al., 2011).

Brand et al. (2018) evaluated the potential of using aciculated dry branches for the production of pellets. The authors recorded a MC after collection of $15,34 \%$ in the same study region, slightly lower than that found in this study when compared to the general average of the collections $(18 \%)$. In the same study, the authors claimed that they even had to add moisture to the raw material up to levels close to $20 \%$ to obtain quality pellets in a flat die pelletizer.

The basic density of the dry branches after grinding in a hammer mill was low $\left(220 \mathrm{~kg} . \mathrm{m}^{-3}\right)$. However, there was a significant variation between the analyzed months (Table 1), with the lowest values observed in the winter and spring, and the highest values in the summer. The low density of biomass fuels is a disadvantage when compared to other fuels because it reduces its energetic density, increasing transport and handling costs, and requiring larger areas for storage (DE PAULA PROTÁSIO et al., 2013). De Paula Protásio et al. (2013), who compared the energetic quality of different types of biomass with fossil fuels, obtained a basic density of 217.58 $\mathrm{kg} . \mathrm{m}^{-3}$ from eucalyptus particles and $232.52 \mathrm{~kg} . \mathrm{m}^{-3}$ from rice husks. These values were close to those obtained from the dry branches. Therefore, the dry branches are similar to other biomasses traditionally used for power generation both in direct burning systems and for obtaining other energetic products.

The relationship between the basic density and the gross calorific value expresses the energetic density of the fuel. It is a fundamental variable for comparing the energetic potential of new fuels to those already currently being used. Similar to the basic density, the energetic density showed significant variation throughout the year. The behavior of the energetic density was similar to the behavior of the basic density, both had a significant and positive correlation between each other $(r=0.85 *)$. On the other hand, the correlation between the gross calorific value and the energetic density was not significant $(\mathrm{r}=0.38 \mathrm{~ns})$.

The energetic densities observed in this study were similar to the eucalyptus particles $\left(997 \mathrm{Mcal}^{-3}\right)$ and coffee residues (bark and endocarp) (1147 Mcal. $\mathrm{m}^{-3}$ ) from another study (DE PAULA PROTÁSIO et al., 2013), which demonstrates the energetic potential of the aciculated dry branches.

Furthermore, we observed higher energetic densities from December to May (summer and autumn), with a decrease in values from June to November (winter and spring), except February which presented a significantly lower value than the months before and after it (Table 1). This characteristic is a disadvantage for energy generation since in the colder months (winter until the beginning of spring) the energetic potential of the dry branches is lower than in the warmer months of the year when the demand for energy, mainly for heating systems, is lower.

The pattern of variation observed in the energetic densities over the analyzed period was the opposite of the one observed in the gross calorific value, which showed a significant variation. The gross calorific value was 
lower in the spring and summer and higher in the autumn and winter. It presented a significant correlation with all the analyzed weather variables, being negative with the average temperature $(r=-0.58)$ and with the average radiation $(\mathrm{r}=-0.73)$, and positive with the relative humidity $(\mathrm{r}=0.63)$.

The average gross calorific value of the dry branches $\left(4761 \mathrm{kcal}_{\mathrm{kg}} \mathrm{kg}^{-1}\right)$ was greater than the one obtained by Brand et al. (2018) (4644 kcal.kg-1), intermediate to the wood with Pinus taeda L. bark (4722 to $4867 \mathrm{kcal}^{. \mathrm{kg}^{-}}$ ${ }^{1}$ ), which is also a Gymnosperm, and higher than the values observed for Eucalyptus dunnii Maiden wood with shell (4494 to $4571 \mathrm{kcal}_{\mathrm{kg}}^{-1}$ ). Both species grew in the same study region and are used for power generation (BRAND et al., 2011).

The proximate analysis of the dry branches varied significantly over the year. The fixed carbon and the volatiles content was lower and higher than the ones observed by Brand et al. (2018), 21.72\% and 70.38\%, respectively. Observing the analyzed properties, the ash content stood out. It presented an increasing trend from June to September (winter), followed by a gradual reduction from October to May (spring, summer, and autumn), except January which had a high ash content and it was similar to June to September. Brand and Muniz (2012) observed the inverse when studying the content of wood ash of Pinus taeda's bark harvested in different periods of the year. This inverse behavior can be explained by the difference between the evaluated materials because they evaluated the wood with bark and we evaluated dry branches with small dimensions.

In addition, all correlations between the weather variables and the ash content were statistically significant. The correlation between the average air temperature and the ash content $(r=-0.64)$, and the correlation between the radiation and the ash content $(r=-0.64)$ were strong and inverse, while the correlation with the average relative humidity was strong and positive $(r=0.65)$ (Table 3$)$.

The average air temperature affects the growth of plants during the seasons, decreasing it in the autumn and winter, which directly and indirectly influences the metabolism of the plants, mainly affecting the photosynthesis and the absorption and translocation of nutrients when the soil's moisture is not limiting. Plant nutrients can be translocated in different plant parts depending on the rainy and dry seasons, plant-growth phase, and greater competition for environmental resources (FONTES et al., 2014; VILLA et al., 2016).

Also, the average ash content was lower than the one observed by Brand et al. (2018) (7.90\%) in the same region and similar to the one obtained by Rios et al. (2015) (5.13\%). The dry branches' ash content can be considered high when compared to the wood with Pinus taeda bark, which varies from 0.4 to $0.6 \%$ (BRAND; DE MUNIZ, 2012). However, it can be considered low when compared to agricultural biomasses such as rice husk, which presents ash contents of around 14\% (BRAND et al., 2017). For energy generation, the lower the ash content, the better the energy use of the fuel and the lower the amount of waste generated after combustion (BRAND, 2010; BRAND et al., 2018).

Moreover, the structural chemical composition showed significant variations throughout the year (Table 2). The lowest extractives contents were observed in the winter and spring, and the highest ones in the summer and autumn. The correlation between the weather variables and the chemical properties of the dry branches confirmed this trend. The average air temperature showed a statistically significant and positive correlation with the extractives soluble in hot water, ethanol, ethanol toluene, total extractives, and the solubility of wood in sodium hydroxide at $1 \%$. Therefore, the increase in temperature contributed to the increase in microbial activity in the soil, which may have resulted in the intensification of the degradation of the biomass that was exposed to these agents.

The relative humidity showed a significant and positive correlation with the lignin content. The solar radiation showed a positive correlation with the extractives and a negative with the lignin content. Therefore, the variations in weather conditions contributed to the variations observed throughout the year in the chemical composition of the dry branches.

The structural chemical composition showed that the major component of the dry branches was lignin, followed by extractives and holocellulose. In general, both levels of total extractives and lignin were high (Table 2 ), which contributed to the generation of energy in combustion processes as these compounds are the ones that have the greatest gross calorific value in the chemical composition of the biomass. The values of soluble extractives in hot water, ethanol, ethanol-toluene, and total extractives obtained in this work were higher than those observed by Rios et al. (2015) and Brand et al. (2018) (Table 4). However, the levels of lignin and holocellulose were lower than those observed by the aforementioned authors for vultures collected in the same study region.

The solubility in sodium hydroxide expresses how soluble a material is in a diluted alkaline solution. It removes extractives and low molecular weight carbohydrates, which mainly constitute some polioses and degraded cellulose. Thus, this analysis indicates the level of decomposition caused by fungi or the degradation by heat, light, oxidation, etc. (ABNT, 2010b). Results showed that the solubility values from October to May (spring, summer, and autumn) were higher, and they decreased from June to September (winter). This behavior indicates a relationship between the speed of biomass degradation in the field and the weather conditions under which the material is subjected. Besides, the correlation between the solubility in sodium hydroxide and the average air temperature was strong, positive, and statistically significant $(r=0.66)$ (Table 3). 
Water-soluble compounds are inorganic elements, tannins, sugars, and gums. The hot water also removes starch (ABNT, 2017b). Results showed that water-soluble extractives presented the highest values from December to February (summer). They reduced in the other months, which expresses the increase in the number of inorganic substances that remained in the dead leaves and thin branches (blades). In the analyzed period, the correlation between the average air temperature and the solubility in hot water $(\mathrm{r}=0.60)$ was positive and significant, and the solar radiation had a significant correlation with the solubility, both in cold water $(r=0.59)$ and hot water $(r=$ $0.61)$.

Also, the extractives soluble in organic solvents (ethanol and ethanol-toluene) and total extracts were significantly influenced by the air temperature $(r=0.71 ; r=0.66$, and $r=0.73$, respectively) (Table 3 ), and the total extractives were also directly influenced by the solar radiation $(r=0.60)$.

Considering all the significant correlations between the weather variables and the properties of the aciculated dry branches, the average air temperature presented a high positive correlation with the gross calorific value, the basic density, the extractives in hot water, in ethanol, in ethanol-toluene, total extracts, and solubility of in sodium hydroxide, and a high negative correlation with the ash content. The relative humidity of the air had a significant and positive correlation with the gross calorific value, the lignin content, and the ash content. The solar radiation had a significant and positive correlation with the basic density, extractives in cold water and hot water and total extracts, and a negative correlation with the gross calorific power, and the ash and lignin contents.

\section{CONCLUSIONS}

- The moisture content of the recently collected dry branches was low during the analyzed period, which means that at any time of the year this biomass can be directly collected and used for power generation without needing prior drying or treatment;

- The gross calorific value and energetic density of the dry branches were high and similar to biomasses traditionally used for energy generation in the study region.

- The A. angustifolia dry branches have the potential to be used as a solid fuel, presenting as a disadvantage the high ash content when compared to wooden biomasses.

- Except for the moisture content, all other physical, structural, and energetic properties of the dry branches varied throughout the year, and they were influenced by the weather variables.

- The monthly average temperature and radiation were the weather variables that influenced more on the physical, chemical, and energetic properties of the dry branches.

- The correlations between the weather variables and the analyzed properties indicated that the energetic quality of the dry branches was better in the summer, with higher monthly average temperatures and solar radiation.

\section{ACKNOWLEDGMENT}

We thank the financial support of the National Council for Scientific and Technological Development CNPQ (Project 441396.207.8/751) and (PQ 311022/2020-0), and the Santa Catarina Research Support Foundation - FAPESC.

\section{REFERENCES}

AMERICAN SOCIETY FOR TESTING AND MATERIALS, ASTM, D 1762 e 84: Standard Test Method for Chemical Analysis of Wood Charcoal, Atlanta, 2013.

ASSOCIAÇÃO BRASILEIRA DE NORMAS TÉCNICAS - ABNT NBR 14929: Madeira - Determinação do teor de umidade de cavacos - Método por secagem em estufa, Rio de Janeiro. 2017a.

ASSOCIAÇÃO BRASILEIRA DE NORMAS TÉCNICAS. ABNT NBR 11941: Madeira: Determinação da densidade básica, Rio de Janeiro, 2003.

ASSOCIAÇÃO BRASILEIRA DE NORMAS TÉCNICAS. ABNT NBR 14577: Pasta celulósica e madeira: Determinação do material solúvel em água, Rio de Janeiro, 2017b.

ASSOCIAÇÃO BRASILEIRA DE NORMAS TÉCNICAS. ABNT NBR 14660: Madeira - Amostragem e preparação para análise, Rio de Janeiro, 2004.

ASSOCIAÇÃO BRASILEIRA DE NORMAS TÉCNICAS. ABNT NBR 7989: Pasta celulósica e madeira Determinação de lignina insolúvel em ácido, Rio de Janeiro, 2010a.

ASSOCIAÇÃO BRASILEIRA DE NORMAS TÉCNICAS. ABNT NBR 7990: Madeira - Determinação do material solúvel em hidróxido de sódio a 1\%, Rio de Janeiro, 2010b. 
BEUTLING, A.; BATISTA, A. C.; SOARES, R. V.; VITORINO, M. D. Quantificação de material combustível superficial em reflorestamentos de Araucaria angustifolia (Bert.) O. Ktze. Floresta, Curitiba, v. 35, n. 3, p. 465472, set/dez, 2005.

BRAND, M. A.; DE MUNIZ, G. I. B.; QUIRINO, W. F.; BRITO, J. O. Storage as a tool to improve wood fuel quality. Biomass and Bioenergy, Birmingham, v. 35, n. 7, p. 2581-2588, July, 2011.

BRAND, M. A.; JACINTO, R. C.; ANTUNES, R.; DA CUNHA, A. B. Production of briquettes as a tool to optimize the use of waste from rice cultivation and industrial processing. Renewable energy, Brighton, v. 111, p. 116-123, October, 2017.

BRAND, M. A. Energia de biomassa florestal. Rio de Janeiro: Interciência, 2010. 114p.

BRAND, M. A.; DE MUNIZ, G. I. B. Influência da época de colheita e da estocagem na composição química da biomassa florestal. Floresta e Ambiente, Rio de Janeiro, v. 19, n. 1, p. 66-78, jan/mar, 2012.

BRAND, M. A.; JACINTO, R. C.; CUNHA. A. B. Qualidade de pellets de galhos secos de araucária e partículas de pinus. Energia na Agricultura, Botucatu, vol. 33, n.4, p. 303-312, out./dez, 2018.

BRASIL. Lei n ${ }^{\circ} 11.428$, de 22 de dezembro de 2006. Dispõe sobre a utilização e proteção da vegetação nativa do Bioma Mata Atlântica, e dá outras providências. Diário Oficial da República Federativa do Brasil, Brasília, DF, vinte e dois de dezembro de 2006. n. 246, seção 1, p. 1-4. Disponível em:< http://www.planalto.gov.br/ccivil_03/_Ato2004-2006/2006/Lei/L11428.htm>. Acesso em: 16 abr 2020.

CALVI, G. P.; PEREIRA, M. G.; ESPÍNDULA JÚNIOR, A. Produção de serapilheira e aporte de nutrientes em áreas de floresta atlântica em Santa Maria de Jetibá, ES. Ciência Florestal, Santa Maria, 19, v. 2, p. 131-138, abr./jun., 2009.

DANNER, M. A.; ZANETTE, F.; RIBEIRO, J. Z. O cultivo da araucária para produção de pinhões como ferramenta para a conservação. Pesquisa Florestal Brasileira, Colombo, v. 32, n. 72, p. 441451, out/nov., 2012.

DE PAUla PROTÁSiO, T.; BUfAlinO, L.; TONOli, G. H. D.; JUNIOR, M. G.; TRUGILHO, P. F.; MENDES, L. M. Brazilian lignocellulosic wastes for bioenergy production: characterization and comparison with fossil fuels. BioResources, Raleigh, v. 8, n. 1, p. 1166-1185, 2013.

DEUTSCHES INSTITUT FÜR NORMUNG, DIN, DIN 51900: 1e3, Testing of Solid and Liquid Fuels. Determining the Gross Calorific Value of Solid and Liquid Fuels Using the Bomb Calorimeter, and Calculation of Net Calorific Value e Part 1-3. Berlin, 2000.

FONTES A.G.; GAMA-RODRIGUES A.C.; GAMA-RODRIGUES E.F.; SALES M.V.S.; COSTA M.G.; MACHADO R.C.R. Nutrient stocks in litterfall and litter in cocoa agroforests in Brazil. Plant and Soil, Perth, v. 383, n. 1-2, p. 313-335, jun., 2014.

HIGUCHI, P.; DA SILVA, A. C.; DE SOUZA FERREIRA, T.; DE SOUZA, S. T.; GOMES, J. P.; DA SILVA, K. M.; ... DA SILVA PAULINO, P. Influência de variáveis ambientais sobre o padrão estrutural e florístico do componente arbóreo, em um fragmento de Floresta Ombrófila Mista Montana em Lages, SC. Ciência Florestal, Santa Maria v. 22, n. 1, p. 79-90, jan./mar., 2012.

IBGE - INSTITUTO BRASILEIRO DE GEOGRAFIA E ESTATÍSTICA. Manual Técnico da Vegetação Brasileira. 2 $2^{\text {a }}$ edição. Rio de Janeiro, 2012.

RIOS, P.; VIEIRA, H. C.; STUPP, Â. M.; KNIESS, D. D. C.; BORBA, M. H.; DA CUNHA, A. B. Avaliação física e mecânica de painéis reconstituídos compostos por partículas de galhos secos de Araucaria angustifolia (Bertol.) Kuntze e madeira de Eucalyptus grandis Hill ex Maiden. Scientia Forestalis, Piracicaba, v. 43, n. 106, p. 283-289, jun., 2015.

VILLA, E. B.; PEREIRA, M. G.; ALONSO, J. M.; BEUTLER, S. J.; LELES, P. S. D. S. Aporte de serapilheira e nutrientes em área de restauração florestal com diferentes espaçamentos de plantio. Floresta e Ambiente, Rio de Janeiro v. 23, n. 1, p. 90-99, jan., 2016.

WATZLAWICK, L. F.; CALDEIRA, M. V. W.; VIERA, M.; SCHUMACHER, M. V.; GODINHO, T. O.; BAILBINOT, R. Estoque de biomassa e carbono na Floresta Ombrófila Mista Montana Paraná. Scientia Forestalis, Piracicaba, v. 40, n. 95, p. 353-362, set., 2012.

ZANETTE, F.; DANNER, M. A.; CONSTANTINO, V.; WENDLING, I. Particularidades e biologia reprodutiva de Araucaria angustifolia. In: WENDLING, I.; ZANETTE, F. (Ed.). Araucária: particularidades, propagação e manejo de plantios. Brasília, DF : Embrapa, 2017. p. 13-39. 